\title{
Agriculture Can Provide Opportunity
}

\author{
Ned Herod* \\ Turf Asset dba Catalyst RVA, USA
}

Submission: September 27, 2017; Published: October 13, 2017

*Corresponding author: Ned Herod, Turf Asset dba Catalyst RVA, Turf Asset LLC, Agricultural Business Development \& Sales Management Nationwide, Lipscomb University, 303 Ralston Road, USA, Tel: 8048394076; Email: nedherod@gmail.com

\section{Opinion}

Having the opportunity to interact within the agriculture industry TWICE is a wonderful, yet interesting, proposition. Having opened agricultural distribution entities now and in the 1980 's, it is in the spirit of the often-asked question, "Well, what is different this time?", that I write this blog.

Well, what is different? In the 80's, society was not dealing with a recent major depression. We were not dealing with the realization of self-inflicted, environmental damage. That was the Ronald Reagan era. Currently, it is more difficult to find influential early adapters. I was very fortunate in the 80 's to find agronomists who said, "I don't want to grow a plant the way everyone does, JUST because everyone else does it that way. I seek a better way". Progression and innovation was prevalent in the 1980's, because agriculture was using 1950'stools (mostare still being used). They were the early adapters of the day. They drove nitrogen use down from the standard 8 - 12 lbs. per year, to 2 - $4 \mathrm{lb}$. levels. They lowered mowing heights. They reduced pesticide usage. They looked outside out of basic chemistry based science. They sought drought resistance. These early adapters drove the agriculture industry. They were "out of the box thinkers" that raised the standards for all.

Change is incredibly difficult for everyone. Do you think that it easy to not start the tractor while everyone else in tilling their fields? All things equal, people will always desire for things to remain the same. I don't think that it is a personal condemnation. I think that it is human nature, it's a "human thing". Few will stand for someone stating, "you are wrong". That would be a fatal mistake for any distributer, or sales representative. We understand that part of a sales representative's responsibility is to correctly position products. Sell the standards to the people that desire the standards. Don't waste time selling a progressive, innovate product to a late adapter. The current challenge is that the 2008 depression is so recent, few are willing to stick their neck out. Are you currently perceived as an "early adapter", or a "never adapter"?

Here is the great news. Change is demanded by society! And this change represents opportunity! Just as it did for those 30 years ago. What we should strive for is multigenerational: product efficiency, and maximizing our investment. The opportunity lies in more efficient, less expense, and more environmentally friendly tools. Progression is coming, whether we desire it, or not. Close minded people are usually job seekers. I'm sorry, age should not factor into the equation.

We currently have more data because of scientific progression. Our focus was chemical, currently, it is biological. Recent science has taught us that a plant, and soil, requires more that nitrogen. They need more than urea. Just as, humans need more than just carbohydrates, or just protein. If we were growing purely indigenous plants, maybe so, but who is? 1970's and 80's Research Institutions taught us about matters within the confines of soil chemistry. Tall Fescue became eerily like Bluegrass. It took the recent scientific research efforts of the TWCA to make a breeding change. Current scientific research has made many discoveries about the soil biological and chemical interaction. In the 80's, carbon was routinely called "inert material". Quite simply, in the past we over-used fertilizer, just in case, the plant might need it later. "Enhanced efficiency" was simply a term used for slowing down the release of a highly inefficient product. For those that are forced to spread granular, outdated options, spoon feeding has displayed a much more efficient means of proving a plant and soil with nutrition. Seek a means of utilizing efficiency-based tools.

There are so many technological advancements now. Science and manufacturing have done their part in developing environmental advancements. Are we doing our part to explore their validity?

The agriculture industry has indeed progressed. In the 1980's we have never grew 400-bushel corn. Farmers did not accomplish this with older 1950's products and science. Progression will continue. Individually, can we choose to participate, or observe.

Changes within agricultural indeed presents a fantastic opportunity. Relish it! Drive it! Explore it! 
This work is licensed under Creative Commons Attribution 4.0 Licens DOI: 10.19080/AIBM.2017.06.555693
Your next submission with Juniper Publishers will reach you the below assets

- Quality Editorial service

- Swift Peer Review

- Reprints availability

- E-prints Service

- Manuscript Podcast for convenient understanding

- Global attainment for your research

- Manuscript accessibility in different formats ( Pdf, E-pub, Full Text, Audio)

- Unceasing customer service

Track the below URL for one-step submission https://juniperpublishers.com/online-submission.php 